\title{
PROBLEMATIKA PELAKSANAAN PENGANGKATAN ANAK (ADOPSI) DITINJAU DARI PERATURAN PEMERINTAH REPUBLIK INDONESIA NOMOR 54 TAHUN 2007 TENTANG PELAKSANAAN PENGANGKATAN ANAK DI PANTI ASUHAN PUTRA BAKTI KABUPATEN BATANG
}

\author{
Zolla Andre Pramono \\ E-mail: zollaandre21@gmail.com \\ Mahasiswa Fakultas Hukum Universitas Sebelas Maret Surakarta \\ Diana Tantri Cahyaningsih \\ E-mail: dianatantri@yahoo.com \\ Dosen Fakultas Hukum Universitas Sebelas Maret Surakarta
}

\begin{abstract}
This article aims to determine the problematic implementation of adoption in terms of the Government Regulation of the Republic of Indonesia Number 54 of 2007 concerning the Implementation of the Appointment of Children at the Putra Bakti Orphanage in Batang Regency. This legal research is a type of empirical legal research that is descriptive. The research approach uses a case and legislation approach. The type of data in the form of primary data where the main data comes from the results of empirical research conducted, and secondary data obtained from literature related to research. Based on the results of the study it can be seen that, the implementation of the adoption carried out by the Putra Bakti Orphanage in the Regency of Batang experienced various problems, which in the implementation of adoption were carried out directly without going through court decisions. The reason for the Putra Bakti Orphanage in Batang Regency to appoint children without conducting a court decision is that parents who raise their children want to establish kinship with their biological parents by adopting children because they assume that the appointment of children in a court is complex and the regulations are too complicated. convoluted and requires a lot of money, takes a long time, the orphanage does not provide special costs in the process of implementing adoption, cultural factors that emphasize the appointment of adoption without going through the court and assume that the community is together, lack of socialization and guidance given or carried out by the government and society, this raises a discrepancy with the Government Regulation of the Republic of Indonesia Number 54 of 2007 concerning the Implementation of Child Appointment which explains that the adoption of the child must be carried out through the court and broken off by the judge.
\end{abstract}

Keywords: Problem; Appointment of Children; Orphanage

\begin{abstract}
Abstrak
Artikel ini bertujuan untuk mengetahui problematika pelaksanaan pengangkatan anak ditinjau dari Peraturan Pemerintah Republik Indonesia Nomor 54 Tahun 2007 tentang Pelaksanaan Pengangkatan Anak di Panti Asuhan Putra Bakti Kabupaten Batang. Penelitian hukum ini merupakan jenis penelitian hukum empiris yang bersifat deskriptif. Pendekatan penelitian menggunakan pendekatan kasus dan perundang-undangan. Jenis data berupa data primer dimana data utama berasal dari hasil penelitian empiris yang dilakukan, serta data sekunder diperoleh dari bahan kepustakaan yang berkaitan dengan penelitian. Berdasarkan hasil penelitian dapat diketahui bahwa, pelaksanaan pengangkatan anak yang dilakukan oleh Panti Asuhan Putra Bakti Kabupaten Batang mengalami berbagai problematika, dimana dalam pelaksanaan pengangkatan anak dilakukan secara langsung tanpa melalui putusan pengadilan. Alasan Panti Asuhan Putra Bakti Kabupaten Batang melakukan pengangkatan anak tanpa melakukan penetapan pengadilan adalah orang tua yang mengangkat anak ingin menjalin kekeluargaan dengan orang tua kandung dengan cara melakukan pengangkatan anak karena mereka beranggapan bahwa pengangkatan anak yang dilakukan di pengadilan tergolong rumit serta peraturan tersebut terlalu berbelit-belit dan membutuhkan banyak biaya, membutuhkan waktu yang lama, pihak panti asuhan
\end{abstract}


tidak menyediakan biaya secara khusus dalam proses pelaksanan pengangkatan anak, faktor budaya masyarakat yang mengedepankan pengangkatan anak tanpa melalui pengadilan dan beranggapan bahwa masyarakat bersifat kebersamaan, kurangnya sosialisasi serta bimbingan yang diberikan atau dilakukan oleh pemerintah dan masyarakat, hal tersebut menimbulkan tidak efektifnya Peraturan Pemerintah Republik Indonesia Nomor 54 Tahun 2007 tentang Pelaksanaan Pengangkatan Anak yang menjelaskan bahwa pengangkatan anak harus dilakukan melalui pengadilan dan di putus oleh hakim.

Kata Kunci: Problematika; Pengangkatan Anak; Panti Asuhan

\section{A. Pendahuluan}

Keluarga merupakan satuan terkecil di masyarakat yang memiliki peranan penting dalam pembangunan berbangsa dan bernegara. Keluarga sendiri sangat berkaitan langsung dalam menentukan kesejahteraan untuk menjalani hidup di masyarakat, sebaliknya jika dalam menjalani kehidupan keluarga mengalami kerusakan ataupun kekacauan maka keluarga tersebut tidak dapat menjalani kehidupan membangun bangsa ataupun bernegara. Mengingat peranan yang dimiliki keluarga sangatlah penting bagi tegak dan sejahteranya masyarakat, maka negara membutuhkan tata tertib serta kaidah-kaidah yang mengatur tentang terbentuknya suatu keluarga (Lulik Djatikumoro, 2011: 1).

Diatur dalam Undang-Undang Nomor 1 Tahun 1974 tentang Perkawinan, Perkawinan adalah ikatan lahir batin antara seorang pria dan seorang wanita sebagai suami istri dengan tujuan membentuk keluarga (rumah tangga) yang bahagia dan kekal berdasarkan Ketuhanan Yang Maha Esa. Dalam perkawinan sendiri diharapkan lahirnya seorang anak yang akan meneruskan garis keturunan. Perkawinan yang sah antara seorang pria dan seorang wanita jika dikaruniai anak melalui perkawinan yang sah, maka anak tersebut menjadi anak yang sah dari kedua orang tuanya (J. Satrio, 2000: 5).

Keinginan orang tua yang besar untuk memiliki anak juga seringkali terbentur akan takdir illahi dimana kehendak orang tua mempunyai anak tidak dapat tercapai. Usaha untuk memperoleh kepemilikan anak yang harus dilakukan yaitu dengan cara melakukan pengangkatan anak. Terdapat instansi pemerintah atau swasta yang menyelenggarakan kegiatan pengangkatan anak untuk menampung anak-anak yang mengalami kurangnya kasih sayang dari orang tua, keterlantaran, ataupun kemiskinan diserahkan ke suatu badan ataupun perseorangan untuk mendapatkan perwalian. Adanya instansi pemerintah atau swasta tersebut memberikan peluang terhadap orang tua yang tidak memiliki anak agar dapat memiliki anak dengan cara mengangkat anak.

Pengangkatan anak bukan sekedar untuk memenuhi kepentingan para calon orang tua angkat saja, melainkan lebih di fokuskan pada kepentingan calon anak angkat. Pengaturan pengangkatan anak bukan sekedar diperlukan untuk memberi kepastian dan kejelasan mengenai pengangkatan anak, tetapi dibutuhkan untuk menjamin kepentingan calon anak angkat, jaminan atas kepastian, keamanan, keselamatan, pemeliharaan, pertumbuhan anak angkat, sehingga pengangkatan anak sendiri memberi peluang pada anak untuk hidup yang lebih sejahtera. Pengaturan pengangkatan anak juga dibutuhkan untuk memastikan pengawasan pemerintah dan masyarakat agar pengangkatan itu dilakukan dengan motif yang jujur (genuine) dan kepentingan anak terlindungi. Dengan kata lain pemerintah berperan aktif dalam proses pengangkatan anak melalui pengawasan dan perizinan (Rusli Pandika, 2012 : 10-11).

Kesejahteraan anak merupakan tanggung jawab utama dari orang tua dalam lingkungan keluarga, tetapi jika hal itu tidak dapat terlaksana maka ada pihak lain yang diserahi hak dan kewajiban tersebut. Jika memang tidak ada pihak yang dapat melaksanakannya, maka sesuai Pasal 34 Undang-Undang Dasar 1945 bahwa fakir miskin dan anak terlantar dipelihara oleh negara, pelaksanaan hak dan kewajiban untuk mewujudkan kesejahteraan anak juga termasuk tanggung jawab negara.

Panti asuhan sendiri sebagai lembaga perwalian yang bertindak sebagai wali bagi anak-anak yang mengalami gangguan ekonomi, anak terlantar, anak yatim piatu, dan anak yang terganggu kesejahteraannya sehingga membutuhkan penanganan dari panti asuhan yang dikelola oleh 
pemerintah maupun dikelola oleh masyarakat. Hal tersebut diatur dalam Pasal 11 Ayat 2 UndangUndang Nomor 4 Tahun 1979 tentang Kesejahteraan Anak bahwa usaha kesejahteraan anak dilakukan oleh pemerintah atau masyarakat.

Tujuan diselenggarakannya panti asuhan adalah untuk memberikan pelayanan sosial yang meliputi perawatan, bimbingan, pendidikan, pengembangan dan rehabilitas, kemudian menyerahkan mereka menjadi anggota masyarakat yang dapat hidup lebih layak dan penuh tanggung jawab sebagaimana mestinya terhadap diri sendiri, keluarga maupun masyarakat. Sedangkan fungsi panti asuhan sendiri adalah sebagai pengganti keluarga dalam mengembangkan pribadi anak yang meliputi aspek fisik, psikis, maupun sosial untuk menyiapkan anak-anak asuh yang berdiri sendiri dan bertanggung jawab baik dalam ekonomi, mental, maupun sosial (Andayani Listyawati, 2008. 23-24). Dengan demikian kondisi anak menjadi lebih matang setelah mereka dibina di panti asuhan dan kemudian anak tersebut diangkat/diadopsi oleh orang tua yang ingin memelihara anak tersebut agar mendapatkan kehidupan yang lebih layak.

Panti Asuhan Putra Bakti merupakan panti asuhan berada di Kabupaten Batang, bergerak di bidang sosial sebagai lembaga pelayanan profesional untuk memberikan perlindungan dan pelayanan kesejahteraan sosial bagi anak yang membutuhkan pengasuhan. Masing-masing anak yang diasuh di Panti Asuhan Putra Bakti memiliki latar belakang berbeda-beda, yaitu anak yatim piatu, anak yatim, anak piatu, anak dari keluarga tidak harmonis, dan anak rawan keterlantaran karena keterbatasan ekonomi. Panti Asuhan Putra Bakti merupakan lembaga pengganti keluarga bagi anak-anak asuh, dimana dalam hal pengurusan anak Panti Asuhan Putra Bakti Kabupaten Batang mementingkan tumbuh kembang anak dengan memberikan pendidikan baik ilmu umum maupun ilmu agama, mengajarkan tentang kedisiplinan, dan keterampilan, sedangkan pelaksanaan pengangkatan anak yang dilakukan Panti Asuhan Putra Bakti Kabupaten Batang bertujuan agar anak dapat hidup layak dan mendapatkan kesejahteraan di dalam keluarga serta memberikan peluang bagi orang tua yang belum dikaruniai anak untuk mendapat kesempatan mengangkat anak dan memiliki anak.

Pada proses pelaksanaan pengangkatan anak yang dilakukan oleh Panti Asuhan Putra Bakti Kabupaten Batang pada kenyataannya tidak sesuai dengan aturan hukum yang berlaku, yaitu dilakukan dengan cara langsung tidak melalui proses penetapan pengadilan. Pihak Panti Asuhan Putra Bakti Kabupaten Batang hanya sebagai saksi, mediasi dalam proses pengangkatan anak serta mempertemukan calon orang tua angkat dengan orang tua kandung. Hal ini menjadikan penulis ingin mengkaji mengenai problematika pelaksanaan pengangkatan anak di Panti Asuhan Putra Bakti Kabupaten Batang menurut Peraturan Pemerintah Republik Indonesia Nomor 54 Tahun 2007 tentang Pelaksanaan Pengangkatan Anak untuk mengetahui dan mendapatkan gambaran yang lebih lanjut.

\section{B. Metode Penelitian}

Penelitian ini merupakan jenis penelitian hukum empiris yang bersifat deskriptif dengan pendekatan kualitatif. Jenis data yang digunakan adalah data primer dan data sekunder. Data primer diperoleh langsung dari Panti Asuhan Putra Bakti Kabupaten Batang sedangkan data sekunder diperoleh dari bahan kepustakaan yang relevan dengan permasalahan yang diteliti. Sumber data yang digunakan adalah primer dan sumber data sekunder yang diperoleh dari bahan hukum primer, sekunder dan tersier. Teknik pengumpulan data yang digunakan adalah wawancara dan studi dokumen atau bahan pustaka.

\section{Hasil Penelitian dan Pembahasan}

Problematika Pelaksanaan Pengangkatan Anak (adopsi) di Panti Asuhan Putra Bakti Kabupaten Batang Ditinjau dari Peraturan Pemerintah Republik Indonesia Nomor 54 Tahun 2007 tentang Pelaksanaan Pengangkatan Anak. 
Adopsi berasal dari kata adoptie, bahasa Belanda atau adopsi (adoption) dalam bahasa Inggris yang berarti pengangkatan anak atau mengangkat anak. Dalam bahasa Arab adopsi dikenal dengan istilah "tabanni yang diartikan dengan "mengambil anak angkat" (Muderis Zaini, 2002: 4).

Pelaksanaan pengangkatan anak di Indonesia banyak dilakukan dan menjadi suatu kebutuhan dalam masyarakat khususnya untuk pasangan suami istri yang telah lama menikah tetapi belum di karuniai keturunan/anak. Masyarakat Indonesia sendiri terdiri dari bermacam-macam suku, agama dan etnis yang menyebabkan bermacam-macam pula motivasi, tata cara bagaiamana pengangkatan anak yang dilakukan oleh masing-masing suku, agama dan etnis tersebut berlangsung.

Pengangkatan anak berdasarkan Peraturan Perundang-Undangan mencakup pengangkatan anak secara langsung dan pengangkatan anak melalui lembaga pengasuhan anak yang dilakukan melalui penetapan pengadilan (Jean K. Matuankotta, 2011. Jurnal Sasi Vol. 17 No.3: 74). Seseorang dapat mengangkat anak paling banyak 2 kali dengan jarak waktu paling singkat 2 tahun. Pengangkatan anak kembar dapat dilakukan sekaligus. Kategori orang tua angkat yang dapat melakukan pengangkatan anak ada dua, yaitu orang tua lengkap suami dan istri warga negara Indonesia atau suami warga negara Indonesia dan istri warga negara asing (Nanik Prasetyoningsih \& Tanto Lailam, 2018. Jurnal Surya Masyarakat Vol. 1 No. 1: 6).

Pengertian Anak Angkat diatur dalam Peraturan Pemerintah Republik Indonesia Nomor 54 tahun 2007 tentang Pelaksanaan Pengangkatan Anak adalah anak yang haknya dialihkan dari lingkungan kekuasaan keluarga orang tua, wali yang sah, atau orang lain yang bertanggung jawab atas perawatan, pendidikan, dan membesarkan anak tersebut, ke dalam lingkungan keluarga orang tua angkatnya berdasarkan keputusan atau penetapan pengadilan.

Syarat-syarat pengangkatan anak sesuai dengan Peraturan Pemerintah Republik Indonesia Nomor 54 Tahun 2007 tentang Pelaksanaan Pengangkatan Anak meliputi calon anak angkat dan calon orang tua angkat. Adapun syarat anak yang akan diangkat berdasarkan Pasal 12 Ayat (2) Peraturan Pemerintah Nomor 54 Tahun 2007 tentang Pelaksanaan Pengangkatan Anak yaitu, merupakan anak terlantar atau ditelantarkan, berada dalam asuhan keluarga atau dalam lembaga pengasuhan anak, memerlukan perlindungan khusus, umur anak harus belum berusia 18 tahun dengan ketentuan:

1. Berusia di bawah 6 tahun merupakan prioritas utama.

2. Berusia 6 tahun sampai dengan 12 tahun sepanjang ada alasan mendesak, yaitu misalnya anak merupakan korban bencana, anak pengungsian, dan sebagainya. Semua ini dilakukan demi kepentingan terbaik bagi anak.

3. Berusia 12 tahun sampai dengan 18 tahun sepanjang anak tersebut memerlukan perlindungan, yaitu misalnya anak dalam situasi darurat, anak yang berhadapan dengan hukum, anak yang diperdagangkan, anak korban penculikan, anak penyandang cacat, dan juga anak korban perlakuan salah dan penelantaran".

Perlu dikemukakan, terdapat beberapa syarat bagi calon orang tua angkat tersebut yang harus dipenuhi berdasarkan Pasal 13 Peraturan Pemerintah Nomor 54 Tahun 2007 tentang Pelaksanaan Pengangkatan Anak. Adapun syarat-syarat tersebut mencakup syarat fisik, syarat agama, syarat moral dan syarat ekonomi.

1. Syarat fisik bagi calon orang tua yang akan mengangkat anak sebagai berikut:

a) Sehat jasmani dan rohani

b) Diharapkan sehat jasmani dan rohani

c) Berumur paling rendah 30 tahun dan paling tinggi 55 tahun.

2. Syarat agama bagi calon orang tua yang akan mengangkat anak:

Harus seagama dengan anak angkatnya karena apabila berbeda akan mempengaruhi tumbuh kembang anak angkatnya tersebut. 
3. Syarat moral bagi calon orang tua yang akan mengangkat anak:

Harus berkelakuan baik dan tidak pernah melakukan tindak kejahatan dan juga harus berstatus menikah paling singkat 5 tahun dan tidak merupakan pasangan sejenis.

4. Syarat ekonomi bagi calon orang tua yang akan mengangkat anak:

Diharapkan calon orang tua angkat dalam keadaan mampu ekonomi dan sosial.

Selain syarat-syarat yang telah disebutkan, calon orang tua juga harus memperoleh persetujuan anak dan izin tertulis orang tua atau wali anak, dan juga membuat pernyataan tertulis bahwa pengangkatan anak adalah demi kepentingan terbaik bagi anak, kesejahteraan dan perlindungan anak. Kemudian calon orang tua angkat juga mempunyai laporan sosial dari petugas sosial setempat, dan telah mengasuh calon anak angkat paling singkat 6 bulan sejak izin pengasuhan diberikan. Serta memperoleh izin Menteri atau kepala instansi sosial.

Peraturan tentang proses permohonan pengangkatan anak yang dilakukan oleh Panti Asuhan Putra Bakti Kabupaten Batang tidak sesuai berdasarkan Peraturan Pemerintah Nomor 54 Tahun 2007 tentang Pelaksanaan Pengangkatan Anak yaitu dijelaskan dalam Pedoman Pelaksanaan Pengangkatan Anak yang diterbitkan oleh Peraturan Menteri Sosial Republik Indonesia Nomor: 110/HUK/2009 tentang Persyaratan Pengangkatan Anak sebagai berikut;

1. Permohonan pengangkatan anak diajukan kepada Instansi Sosial Kabupaten/Kota dengan melampirkan:

a) Surat penyerahan anak dari orang tua/walinya kepada instansi sosial;

b) Surat penyerahan anak dari Instansi Sosial Propinsi/Kab/Kota kepada Organisasi Sosial (orsos);

c) Surat penyerahan anak dari Organisasi Sosial (Orsos) kepada calon orang tua angkat;

d) Surat keterangan persetujuan pengangkatan anak dari keluarga suami-istri calon orang tua angkat;

e) Fotokopi surat tanda lahir calon orang tua angkat;

f) Fotokopi surat nikah calon orang tua angkat;

g) Surat keterangan sehat jasmani dan rohani berdasarkan keterangan dari Dokter Pemerintah;

h) Surat keterangan sehat secara mental berdasarkan keterangan Dokter Pksiater;

i) Surat keterangan penghasilan dari tempat calon orang tua angkat bekerja.

2. Permohonan izin pengangkatan anak diajukan pemohon kepada Kepala Dinas Sosial/Instansi Sosial Propinsi/Kab/Kota dengan ketentuan sebagai berikut:

a) Ditulis tangan sendiri oleh pemohon di atas kertas bermaterai cukup;

b) Ditandatangani sendiri oleh pemohon (suami-istri);

c) Mencantumkan nama anak dan asal usul anak yang diangkat.

3. Dalam hal calon anak angkat tersebut sudah berada dalam asuhan keluarga calon orang tua angkat dan tidak berada dalam asuhan organisasi sosial, maka calon orang tua angkat harus dapat membuktikan kelengkapan surat-surat mengenai penyerahan anak dan orang tua/ wali keluarganya yang sah kepada calon orang tua angkat yang disahkan oleh instansi sosial tingkat Kabupaten/Kota setempat, termasuk surat keterangan kepolisian dalam hal latar belakang dan data anak yang diragukan (domisili anak berasal).

4. Proses Penelitian Kelayakan.

5. Sidang Tim Pertimbangan Izin Pengangkatan Anak (PIPA) Daerah.

6. Surat Keputusan Kepala Dinas Sosial/Instansi Sosial Propinsi/Kab/Kota bahwa calon orang tua angkat dapat diajukan ke Pengadilan Negeri untuk mendapatkan ketetapan sebagai orang tua angkat. 


\section{Penetapan Pengadilan.}

8. Penyerahan Surat Penetapan Pengadilan".

Pelaksanaan pengangkatan anak (adopsi) yang dilakukan oleh Panti Asuhan Putra Bakti Kabupaten Batang berawal dari seorang wanita yang datang ke Panti Asuhan Putra Bakti Kabupaten Batang dengan membawa anak yang masih berumur 4 tahun, wanita tersebut datang ke Panti Asuhan Putra Bakti Kabupaten Batang untuk menitipkan anaknya karena wanita tersebut mengalami kekurangan ekonomi dan takut tidak bisa mensejahterakan kehidupan sang anak untuk ke depannya karena wanita tersebut hanya hidup sendiri tanpa ada suami yang menemaninya. Melihat hal tersebut pengurus Panti Asuhan Putra Bakti Kabupaten Batang menerima atas kehadiran anak tersebut dan diizinkan untuk anak tersebut tinggal di Panti Asuhan Putra Bakti Kabupaten Batang. Panti Asuhan Putra Bakti Kabupaten Batang menerima anak tersebut untuk diasuh karena asal-usulya jelas dan ada ibu kandungnya, pihak panti asuhan juga mementingkan terbaik bagi anak untuk mendapatkan kesejahteraan dalam menjalani kehidupannya. Setelah beberapa bulan anak tersebut tinggal di Panti Asuhan Putra Bakti Kabupaten Batang ada orang tua yang datang mengunjungi Panti Asuhan Putra Bakti Kabupaten Batang dengan tujuan ingin mengangkat anak karena orang tua tersebut sudah melaksanakan perkawinan namun belum juga dikaruniai anak. Melihat ada anak yang masih berusia 4 tahun berada di Panti Asuhan Putra Bakti Kabupaten Batang orang tua tersebut berniat ingin mengangkat anak. Pihak Panti Asuhan Putra Bakti Kabupaten Batang mempertemukan calon orang tua angkat dengan orang tua kandung untuk melakukan suatu persetujuan guna memperlancar pengangkatan anak. Panti Asuhan Putra Bakti Kabupaten Batang juga akan menghimbau kepada calon orang tua angkat tersebut agar tetap saling menjaga hubungan baik antara calon anak angkat dengan orang tua kandungnya. Kesepakatan ini biasanya dilakukan hanya secara lisan yang disaksikan oleh para keluarga dari masing-masing pihak serta peran Panti Asuhan Putra Bakti Kabupaten Batang sebagai mediasi dan saksi dalam pelaksanaan pengangkatan anak. Jika kedua belah pihak antara keluarga kandung dan orang tua angkat terjadi kesepakatan, maka anak yang akan diangkat tersebut bisa melakukan serah terima. Serah terima yang dimaksud adalah proses penyerahan anak angkat dari orang tua kandung kepada orang tua angkat dan juga penyerahan segala tanggung jawab yang seharusnya dilakukan orang tua kandung karena ketidakmampuan orang tua kandung kepada orang tua angkat sesuai dengan tujuan untuk mensejahterakan kehidupan anak angkat tersebut. Setelah semua pihak sepakat dengan cara anak angkat sudah diserahkan kepada orang tua angkat, maka tugas dari orang tua angkat kepada anak angkat untuk melakukan kewajiban layaknya orang tua kandung tersebut dengan memberikan anak angkat berupa pendidikan yang layak, baik pendidikan jasmani maupun rohani, memenuhi segala kebutuhan anak angkat yang sebelumnya anak angkat belum dapatkan dari orang tua kandungnya karena keterbatasan ekonomi, memberikan kasih sayang, bimbingan moril ataupun materil yang tentu saja tidak keluar dari aturan-aturan agama.

Dari penjelasan di atas bahwa dalam praktek pelaksanaan pengangkatan anak (adopsi) yang berada di Panti Asuhan Putra Bakti Kabupaten Batang dilakukan secara langsung tidak melalui penetapan pengadilan, dengan cara pihak Panti Asuhan Putra Bakti Kabupaten Batang hanya sebagai saksi dalam proses pengangkatan anak serta sebagai pihak yang mempertemukan antara calon orang tua kandung dengan orang tua angkat. Hal tersebut tidak sesuai dengan pengaturan mengenai proses pengangkatan anak diatur di dalam Pasal 20 Peraturan Pemerintah Nomor 54 Tahun 2007 tentang Pelaksanaan Pengangkatan Anak mengenai tata cara pengangkatan anak yang berbunyi:

1. Permohonan pengangkatan anak telah memenuhi persyaratan diajukan ke pengadilan untuk mendapatkan penetapan pengadilan,

2. Pengadilan menyampaikan salinan penetapan pengangkatan anak ke instansi terkait".

Alasan Panti Asuhan Putra Bakti Kabupaten Batang melakukan pengangkatan anak tanpa melakukan penetapan pengadilan yang diatur sesuai dengan Peraturan Pemerintah Republik Indonesia Nomor 54 Tahun 2007 tentang Pelaksanaan Pengangkatan Anak terdapat dua faktor, diantaranya adalah: 
1. Faktor Internal

Orang tua yang mengangkat anak ingin menjalin kekeluargaan dengan orang tua kandung dengan cara melakukan pengangkatan anak demi mewujudkan kesejahteraan bagi anak yang mengalami masalah sosial dalam hal pendidikan, pembiayaan sehari-hari, memberikan kasih sayang kepada anak angkat layaknya seperti orang tua kandung.

2. Faktor Ekternal

a. Pengangkatan anak yang dilakukan di pengadilan tergolong rumit serta peraturan tersebut terlalu berbelit-belit dan membutuhkan banyak biaya karena calon orang tua angkat harus melengkapi persyaratan administrasi demi terwujudnya pelaksanaan pengangkatan anak jika melalui pengadilan,

b. Membutuhkan waktu yang lama untuk memenuhi ketentuan suatu peraturan pengangkatan anak (adopsi) melalui putusan pengadilan,

c. Pihak panti asuhan tidak menyediakan biaya secara khusus dalam proses pelaksanan pengangkatan anak karena panti asuhan lebih menekankan pada fungsi sosialnya untuk mensejahterakan anak-anak didalam panti asuhan yang mengalami permasalahan ekonomi,

d. Faktor budaya masyarakat yang mengutamakan kepentingan pengangkatan pengangkatan anak tanpa melalui pengadilan dan beranggapan bahwa masyarakat bersifat kebersamaan atau komunal yang kuat, artinya manusia menurut hukum adat merupakan makhluk dalam ikatan kemasyarakatan yang erat meliputi seluruh lapangan hukum dan hukum adat juga beranggapan bahwa perhubungan hukum dianggap hanya terjadi karena ditetapkan dengan suatu ikatan yang dapat dilihat. Dengan demikian pengangkatan anak bagi masyarakat Indonesia mempunyai sifat kebersamaan antar berbagai daerah hukum,

e. Kurangnya sosialisasi serta bimbingan yang diberikan atau dilakukan oleh pemerintah dan masyarakat terhadap pelaksanaan pengangkatan anak (adopsi) melalui kegiatan penyuluhan, konseling, konsultasi, dan pendampingan. Hal tersebut mengakibatkan kurangnya pengetahuan masyarakat mengenai pelaksanaan pengangkatan anak (adopsi), bagaimana pengangkatan anak (adopsi) mampu memperbaiki kehidupan yang dialami anak dengan pengasuhan yang baik, dan pentingnya kepastian hukum atas kedudukan anak angkat di dalam keluarga.

Demi kepentingan terbaik anak agar mendapatkan kehidupan yang lebih layak dan mendapat kasih sayang di dalam keluarga maka di dalam Pasal 9 Undang-Undang Republik Indonesia Nomor 35 Tahun 2014 tentang Perubahan Atas Undang-Undang Nomor 23 Tahun 2002 tentang Perlindungan Anak disebutkan bahwa anak berhak mendapatkan pendidikan dan pengajaran dalam rangka pengembangan pribadinya dan tingkat kecerdasannya sesuai dengan minat dan bakat, anak berhak mendapatkan perlindungan di satuan pendidikan dari kejahatan seksual dan kekerasan yang dilakukan oleh pendidikan, tenaga kependidikan, sesama peserta didik, dan/atau pihak lain, serta anak penyandang disabilitas berhak memperoleh pendidikan luar biasa dan anak yang memiliki keunggulan berhak mendapatkan pendidikan khusus.

Pengangkatan anak (adopsi) pada dasarnya harus dilakukan melalui proses hukum dan di tetapkan oleh hakim melalui pengadilan. Proses hukum tersebut bertujuan agar tertibnya praktek hukum dalam proses pelaksanaan pengangkatan anak (adopsi) yang hidup di tengah-tengah lingkungan masyarakat agar peristiwa pengangkatan anak (adopsi) di kemudian hari memiliki kepastian hukum yang jelas baik bagi anak maupun bagi orang tua angkat. Pengangkatan anak (adopsi) merupakan salah satu perbuatan hukum dan jika dilakukan melalui prosedur penetapan hakim yang diputus oleh pengadilan maka status kepastian hukum dan kedudukan anak menjadi lebih jelas. Penetapan pengadilan juga merupakan bukti akan keseriusan orang tua angkat untuk menerima anak tersebut masuk ke dalam lingkup keluarga mereka dengan segala konsekuensi yang ditimbulkannya. 


\section{Simpulan}

Pelaksanaan pengangkatan anak (adopsi) yang berlangsung di Panti Asuhan Putra Bakti Kabupaten Batang dilakukan secara langsung tanpa melakukan penetapan pengadilan dan disaksikan oleh pihak keluarga saja, karena alasan sebagai berikut:

1. Pengangkatan anak yang dilakukan di pengadilan tergolong rumit serta peraturan tersebut terlalu berbelit-belit dan membutuhkan banyak biaya,

2. Membutuhkan waktu yang lama untuk memenuhi ketentuan suatu peraturan pengangkatan anak (adopsi) melalui putusan pengadilan,

3. Pihak panti asuhan tidak menyediakan biaya secara khusus dalam proses pelaksanan pengangkatan anak karena panti asuhan lebih menekankan pada fungsi sosialnya untuk mensejahterakan anak-anak di dalam panti asuhan yang mengalami permasalahan ekonomi,

4. Faktor budaya masyarakat yang mengepentingkan pengangkatan anak tanpa melalui pengadilan dan beranggapan bahwa masyarakat bersifat kebersamaan atau komunal yang kuat, artinya manusia menurut hukum adat merupakan makhluk dalam ikatan kemasyaraatan yang erat meliputi seluruh lapangan hukum, dan hukum adat juga beranggapan bahwa perhubungan hukum dianggap hanya terjadi karena ditetapkan dengan suatu ikatan yang dapat dilihat,

5. Kurangnya sosialisasi serta bimbingan yang diberikan atau dilakukan oleh pemerintah dan masyarakat terhadap pelaksanaan pengangkatan anak (adopsi) melalui kegiatan penyuluhan, konseling, konsultasi, pendampingan serta pelatihan.

Hal tersebut menunjukkan bahwa pengangkatan anak (adopsi) yang dilakukan di Panti Asuhan Putra Bakti Kabupaten Batang tidak sesuai dengan Pasal 20 Peraturan Pemerintah Nomor 54 Tahun 2007 tentang Pelaksanaan Pengangkatan Anak.

\section{E. Saran}

Dalam praktek pelaksanaan pengangkatan anak yang terjadi di masyarakat hendaknya pemerintah memberikan aturan yang lebih mudah, jelas, dan tegas tentang pelaksanaan pengangkatan anak, karena pengangkatan anak (adopsi) merupakan salah satu perbuatan hukum dan jika pelaksanaannya dilakukan melalui prosedur penetapan pengadilan maka status kepastian hukum dan kedudukan anak menjadi lebih jelas.

\section{F. Daftar Pustaka}

Andayani Listyawati. 2008. Penanganan Anak Terlantar melalui Panti Asuhan Milik Perorangan. Yogyakarta: B2P3KS Press

Ika Putri Pratiwi. 2016. "Akibat Hukum Pengangkatan Anak yang Tidak Melalui Penetapan Pengadilan". Jurnal Hukum Magister IImu Hukum dan Kenotariatan. Malang. Fakultas Hukum Universitas Brawijaya

Jean K. Matuankotta. 2011. "Perlindungan Hukum Terhadap Anak Angkat dalam Memperoleh Kejelasan Status Hukum Melalui Pencatatan Pengangkatan Anak" (Suatu Tinjauan dari Perspektif Hak Asasi Manusia). Jurnal Sasi Vol. 17 No.3 Bulan Juli-September 2011. Ambon. Fakultas Hukum Universitas Pattimura

J. Satrio. 2000. Hukum Keluarga Tentang Kedudukan Anak dalam Undang-Undang. Purwokerto : PT. Citra Aditya Bakti

Lulik Djatikumoro. 2011. Hukum Pengangkatan Anak di Indonesia. Bandung : PT Citra Aditya Bakti

Muderis Zaini. 2002. Adopsi Suatu Tinjauan dari Tiga Sistem Hukum : Penerbit Sinar Grafika, Jakarta 
Muhammad Heriawan. 2017. "Pengangkatan Anak Secara Langsung dalam Perspektif Perlindungan Anak". Jurnal Katalogis, Volume 5 Nomor 5, Mei 2017. Sulawesi Tengah. Fakultas Hukum Universitas Tadulako

Nanik Prasetyoningsih dan Tanto Lailam. 2018. "Pendampingan Penanggulangan dan Penyelesaian Kasus Adopsi Anak dan Tindak Kekerasan dalam Rumah Tangga”. Jurnal Surya Masyarakat Vol. 1 No. 1. Semarang. Lembaga Penelitian dan Pengabdian Masyarakat Universitas Muhammadiyah Semarang

Rusli Pandika. 2012. Hukum Pengangkatan Anak. Jakarta : Sinar Grafika

Sri Suwarni dan R. Tri Yuli Purwono. 2017. "Pelaksanaan Pengangkatan Anak dalam Perpektif Peraturan Pemerintah Republik Indonesia Nomor 54 Tahun 2007 di Kabupaten Bantul". Jurnal Kajian Hukum Vol.2 No.1. Yogyakarta. Fakultas Hukum Universitas Janabadra 